\title{
DEALING WITH THE CONSEQUENCES OF CLIMATE CHANGE IN HISTORIC PARKS AND GARDENS IN THE UNITED KINGDOM
}

\begin{abstract}
Given that long term climate change is recognised as having an >impact upon all aspects of daily life, not least the survival of heritage assets there is a need to consider all aspects of heritage in the United Kingdom (UK). In order to provide an international context for the German situation this paper looks specifically at adaptation measures that have developed within the main British conservation and horticultural organisations, Historic England, the National Trust and the Royal Horticultural Society. It does this by providing some cultural context for the present policies. It then looks at how the climate is expected to change by the end of this century. It identifies the main challenges, and then reviews the responses by way of adaptation and mitigation.
\end{abstract}

Wenn man davon ausgeht, dass der langfristige Klimawandel als etwas begriffen wird, das »Einfluss auf alle Aspekte des täglichen Lebens, und nicht nur auf das Überleben des kulturellen Erbes« haben wird, ist es notwendig alle Formen des kulturellen Erbes im Vereinigten Königreich (UK) zu berücksichtigen. Um die deutsche Situation in einen breiteren, internationalen Kontext stellen zu können, widmet sich dieser Beitrag explizit den Anpassungsstrategien, die sich innerhalb der wichtigsten britischen Naturschutz- und Gartenbauorganisationen, Historic England, National Trust und Royal Horticultural Society, herausgebildet haben. In diesem Zusammenhang wird der kulturelle Kontext für die derzeit geltenden Richtlinien erläutert. Zudem wird auf die erwarteten klimatischen Veränderungen bis zum Ende dieses Jahrhunderts eingegangen. Der Beitrag identifiziert wesentliche Herausforderungen und wertet mögliche Strategien der Anpassung und Schadensminimierung aus.

\section{Introduction}

In the light of overwhelming national issues and concerns, the recent climate change debate in the United Kingdom (UK) reveals a resignation that the climate is changing, but that 
parks and gardens can make a contribution to slow down this process, or at least not aggravate it, by creating landscapes that are both carbon neutral and sustainable. This paper explores how climate change adaptation and mitigation has been resolved within the context of the three major institutions; Historic England, The National Trust and the Royal Horticultural Society provide policies and guidance that are followed more widely than in the institutions alone. Initially they collaborated, but more recently each has produced its own guidance, revealing not only different organisational objectives, but also changing priorities in conservation of parks and gardens. These policies disclose how climate change narratives sometimes clash with those of conservation.

\section{The perception of climate change in the United Kingdom}

While climate change is an increasing concern, in the UK it has rather taken a back seat over the past few years as Brexit, the National Health Service and the migrant crisis have taken precedence as being more pressing. It is not surprising then that $38 \%$ of the British population were not or not very worried about climate change. This is a higher percentage than in the other three western countries that contributed to a 2016 survey, with France the lowest at $21 \%$ (Steentjes et al. 2017, 43).

The policies since Brexit have developed a slant that reinforces political beliefs, and deal with some of the consequences, rather than confronting the issue of climate change. Thus narratives of plant diseases match the political narrative of the need for adequate border protection to prevent entry into the country, something that is not covered by EU regulations. While pathogens are frequently transported with nursery stock, they only become established when plants are weakened and conditions are suitable due to environmental change. The latest case is that of Xylella fastidiosa, a bacterial disease that is spread by the common meadow spittlebug that feeds on the xylem fluid of woody plants. This disease has recently spread from Italy and the south of France to Spain. While it is not known in the UK there has been widespread concern leading to demands for greater control of imports of nursery stock (See Department for Environment, Food and Rural Affairs n.d). While warmer conditions and increased stress in plants through extreme conditions does increase the incidence of new pests and pathogens, ${ }^{1}$ this erecting of barriers sits well with the political narrative, but does not deal with the real issue of climate change.

\section{The main issues relating to parks and gardens caused by climate change}

In 2002 the main climate impact was articulated in a UK Climate Impacts Programme briefing report Climate Change Scenarios for the United Kingdom. It predicted ' wetter win- 
ters and substantially drier summers, and some conditions that we now consider highly unusual could become commonplaces:

By 2080 the annual temperature is expected to rise between 2 and $3.5^{\circ} \mathrm{C}$, with the south and east of the country up to $5^{\circ} \mathrm{C}$ warmer in summer. Such high summer temperatures were expected to become more frequent and very cold winters increasingly rare. This would be associated with wetter winters and drier summers, with winter precipitation up by $30 \%$ and summer soil moisture down by up to $40 \%$. Yet while winter precipitation will become more frequent, the amounts of snowfall will decrease between 60 and $90 \%$. Relative sea levels were expected to rise between 2 and $58 \mathrm{~cm}$ in western Scotland, but between 26 and $86 \mathrm{~cm}$ in southeast England. Associated with this, extreme sea levels might occur between 10 and 20 times more frequently. It was also thought that the Gulf Stream might weaken, and the report was produced with this in mind, though it was noted that factors that control ocean circulation were not understood enough to provide more accurate predictions (Hulme et al. 2002, 1f.).

A technical report Gardening in the Global Greenhouse: The impacts of climate change on gardens in the UK (2002) investigated the potential impacts of projected scenarios of climate change on gardens and identified three interrelated phenomena. The first was climate change as summarised in the briefing report (above), with the increasing frequency of extreme weather events such as floods and droughts noted as the second phenomenon, and the third one being development. The latter includes changes to the earth's surface as a result of human activity, but also increasing traffic and travel and the increasing spread of pests and diseases. Increasing $\mathrm{CO}_{2}$ levels will affect plant growth, bud break in fruit trees, and may hasten maturity. Higher temperatures will accelerate loss of organic matter in soils, releasing nitrogen, which may increase plant growth, but also potentially water pollution. The severity of pests and diseases is likely to increase, as will the geographical area of weeds currently at the edge of their climate range. Temperature increases and summer droughts will cause stress considerable. In three case studies included in their report the authors conclude that the many plants and gales and flood will further challenge growth. While to some extent this can be accommodated within gardens through management and opportunities to grow new plants, this is likely to be an issue for gardens of significant historic interest. The costs of adaption involved in conserving as far as possible the ,form and content ' of these gardens were thought to be considerable. In three case studies included in their report the authors conclude that the main issue main issue is drier conditions in the summer (Bisgrove/Hadley 2002, iii, vii-ix, 139).

It was this belief that was taken forward by the National Trust in their 2010 travelling exhibition on climate change entitled `A plant in time . This included three paintings by Rob Collins, which feature a typical, but imaginary National Trust property, with a house set in parkland with lake. There is a small formal garden in the foreground and a house concealed by half-standard fruit trees. Next to the house is a large cedar and there is a veteran oak in the park; the park is green and lush, with Friesian cows grazing, and the garden is abundant and green with traditional perennial flower borders and roses. In the second painting (plus 
$2^{\circ} \mathrm{C}$ ) the grass has yellowed, clearly stressed by drought; the large cedar and oak are both in decline; the meadows have been replaced by scorched fields with olive trees and the cows by goats. The waterbody has dried up but provides the greenest grass and the garden contains a more exotic mix of summer flowers and bulbs and in its centre the original standard roses have been replaced by orange trees. In the third painting (plus $4^{\circ} \mathrm{C}$ ) there is no grass; the cedar and oak have disappeared and have been replaced by palm trees. The fields have olive trees, and the orange trees have matured within the garden, where grass has been replaced with gravel. There are banana plants and agaves in the borders, and a bougainvillea in the foreground. The underlying message is only marred by the fact that this scene is as familiar as that of a Mediterranean holiday, providing not only a comforting feeling, but also a secret desire perhaps for climate warming to roll on. The reality however may be very different (Plates XIV, XV, XVI).

Some of the factors that influence the British climate and their impact have not been considered sufficiently but are likely to be considerable. One of the main factors is the North Atlantic Current (NAC or `Gulf Stream`). This is part of the North Atlantic heat conveyor that brings warm currents from the tropics to the Atlantic Ocean and up towards western Europe. The NAC is the last section of this conveyor and ensures that average temperatures there are well above those of this latitude. In other words, the mild climate of Great Britain is as a result of the NAC, but the evidence is that since 1992 this has weakened, possibly by $30 \%$, whereas subtropical recirculation has increased by the same amount. This, in turn, is affecting the position of areas of high and low pressure and also of the jet stream. So rather than warmer and sub-tropical this appears to provide a basis for predicting that there may also be cooling, and with a more versatile jet stream, irregular weather patterns and storms. This is the evidence after the Great Storms of 1987 and 1990. Since then the weather pattern has continued to fluctuate with records of the wettest month, driest spell, coldest and hottest temperatures, early and late snow, heavy rain and increased incidence of flooding, etc., continuing to be broken on an almost annual basis.

Thus, as in other countries, some of the main challenges for the UK in the management of historic parks and gardens will lie in water management with respect to flooding and droughts, management of pests and diseases, vegetation and plant growth, visitors and unpredictable events. ${ }^{2}$

\section{Responding to the consequences of climate change}

In 2017 the Royal Horticultural Society commissioned a new report, Gardening in a Changing Climate, written by staff of the Universities of Sheffield and Reading. This explored the

2 Cf. chapter »Naturräumliche Ausstattung « in this volume. For more information, see Bisgrove/Hadley 2002; Hitchmough et al. 2010; Fluck 2016; Webster et al. 2017. 
>intrinsic link between gardens and climate change`, summarised the implications, and outlined ways sin which gardeners can both adapt to a changing climate, but also mitigate against further greenhouse gases $`$. It concluded that, according to the 2002 report, greenhouse gas emissions had followed the trajectory of the highest emission scenarios, and that these will affect the speed of climate change, something that was already felt by many gardeners. As an organisation that mainly caters for amateur gardeners, the implications are clearly spelled out, as are adaptive and (mainly) mitigation measures: `Green your living space in order to harness $\mathrm{CO}_{2}$ from the atmosphere; >plant a diverse range of plants ; >adopt new ways of growing «; >avoid peat «; >compost your garden and kitchen waste`; >adopt the 4R's`, reduce/reuse/recycle/reinvest; avoid chemicals; ‘practice Integrated Pest Management «; control disposal of plants so as not to generate new >invasive species. One of the main conclusions of this practically intended report is that the role of gardens in climate change mitigation has been overlooked, and as a result >specific management practices to achieve this remain largely unknown . While this report includes interviews with gardeners of historic parks and gardens, conservation or heritage were not part of its remit (Webster et al. 2017, 79f.).

As the main private conservation organisation The National Trust promotes protection of the environment and by example strives to sprevent avoidable damage caused by human impact $`$ and to protect `long-term interests from environmental damage . It envisages this being achieved through sustainable management, not just environmentally. It also believes that >truly sustainable gardens should also engage and excite visitors $\lessdot$. This means an important objective is the maintaining of >quality and historic integrity`, but also its various plant collections. Besides reducing costs and maintenance, and implementing its environmental footprint targets the Trust thus aims to assume a leadership role in sustainable practice, ensuring that /gardens become more resilient to environmental changes<.

A report commissioned to challenge common barriers to implementing sustainable practices and exploring pathways for implementation was commissioned with academics from the University of Sheffield, collaborating with National Trust staff. They provided practical examples in case studies to show that igarden teams can be the force to translate Trust policy into real achievements, not just at the level of the garden, but also for the sustainability of the property as a whole . They did this by organising the case studies in three levels of environmental standards: bronze, silver and gold. Bronze level standards are often already in place. They are: `low-cost, unobtrusive and feasible for most gardens`, with the following targets: using energy and water efficiently; optimising use of rainwater; composting garden waste; re-using and recycling materials, and incorporating a full integrated pest management programme. The silver level standards involve: using low energy management techniques; recycling grey water; reducing water demand; composting catering waste, and reducing use of synthetic chemicals. The gold level standards aim for a carbon neutral, waste neutral garden, and its targets are: increasing use of renewable energy; not using electricity for garden operations; composting all garden and catering waste; not using synthetic chemicals under integrated pest management; ‘a climate adaptation plan (for garden and plant 


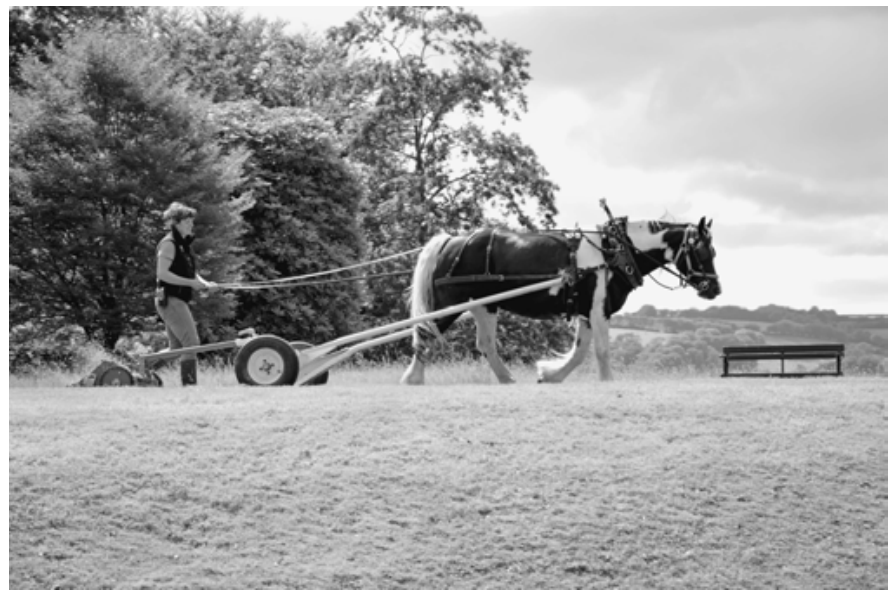

1 National Trust staff is encouraged to innovate with more sustainable practices, such as here at Arlington Court, Devon, where horses are used to mow the lawns.

collection) in place for future planting ‘ and slinks with the wider estate, for example, as a source of bio-fuel and edible crops< (Hitchmough et al. 2010, 1-5) (Fig. 1).

These standards have been integrated into the Key Performance Indicators that are measured and summarised annually in a Conservation Performance Indicator national report, with a summary in the Trust's Annual Report. For example, the 2016/17 report noted that $>$ Gardens and parks performed particularly well, with $94 \%$ showing a static or improved score. $<$ This was linked to simproved health care standards, better replanting and repairs, and good conservation management planning` (National Trust 2017, 6).

Historic England, the government quango for the historic environment, takes a different approach. Unlike English Heritage from which it emerges, it no longer has responsibility for government owned heritage assets. They have been managed since 2015 by the English Heritage Trust. It thus acts as a statutory adviser and consultee on all aspects of the historic environment and its heritage assets, making climate change one of its priorities. Its response to the challenge of how climate change affects the historic environment is therefore more strategic. It highlights climate change as a >risk multiplier«, which exacerbates less significant threats thereby creating new and unforeseen challenges. It suggests two areas of response, in mitigation - >reducing our impact upon the causes of climate change - and adaptation - >adapting to the changes that are already, or will occur $<$. It notes that heritage is >not only affected by the impacts of climate change, but also by our responses to it, e.g. flood defences, sustainable energy generation and improving energy efficiency of buildings (Historic England n.d.).

As a consequence of the Climate Change Act, 2008, it was required by law to report on climate change adaptation. This was used as an opportunity sto think differently and review existing practices and processes $\triangleleft$. It reviewed this in both mitigation, >taking action to increase energy efficiency and sustainability، thereby reducing the general contribution of 
greenhouse gases`, and in adaptation - >anticipating the adverse effects of climate change and taking appropriate action to prevent or minimise damage tation Report (2016) makes seven recommendations: >Maintain a "watching brief « on climate change projections and their associated environmental impacts «; ২Support workforce resilience ; `Support resilience in the historic environment $`$; Embed climate change adaptation and environmental risk management within projects and practices $`$; Promote the positive role the historic environment can play in informing responses to climate change and associated environmental risks`; `Develop an approach for dealing with inevitable change, including loss`, and `Support English Heritage Trust in addressing climate change impacts (Fluck 2016, 19-21). Historic England has not made a direct statement regarding climate change adaptation, though it is a permeating issue in their `Landscape Advice Notes`, available online, which deal with issues such as problem weeds, peat policy and green waste management for English Heritage properties, treatment of dead wood in historic parks and gardens, and various diseases, such as horse chestnut bleeding canker (Pseudomonas syringae pv. aesculi) and sudden oak death (Phytophthora ramorum). More recently the latter have been linked with similar information leaflets produced by the Forestry Commission which deal with a wider range of diseases that have become prevalent in the British landscape. $^{3}$

However, Jenifer White, the National Landscape Adviser for Historic England, emphasised the need to build resilience to climate change, to plan for adaptation not only for the individual impacts, but also the cumulative effects and geographical variations across the country, over time and into the twenty-second century. She notes that the significance of an individual site and conservation aims need to be well understood in order to assess impacts and sustainability.< The English Heritage Conservation Principles (2007) were recommended as a useful basis for making adaptation decisions. Since all adaptation potentially confuses historic designs and interpretation, any change should aim to >retain the significance and qualities of sites. $<$ Additionally, climate change adaptation needs $>$ to be integrated with ongoing adjustment, removal and replacement of plantings. $<$ This in turn will affect management programmes, staffing and budgets of gardens. Consequently, monitoring and review are important when it comes to defining successful strategies, as is detailed documentation.

The significance of the Conservation Management Plan - a management tool developed as a response to the Burra Charter (ICOMOS Australia, 1982) and widely adopted in the UK - is stressed here as a way of developing an >understanding about heritage significance, vulnerabilities, sustaining values and managing change of individual sites.« Such conservation management plans should be reviewed regularly. Having one for each site >would help move towards a planned, rather than reactive, approach to adaptation for our designed

3 See https://historicengland.org.uk/advice/technical-advice/parks-gardens-and-landscapes/pests-anddiseases/ (13.11.2018). 


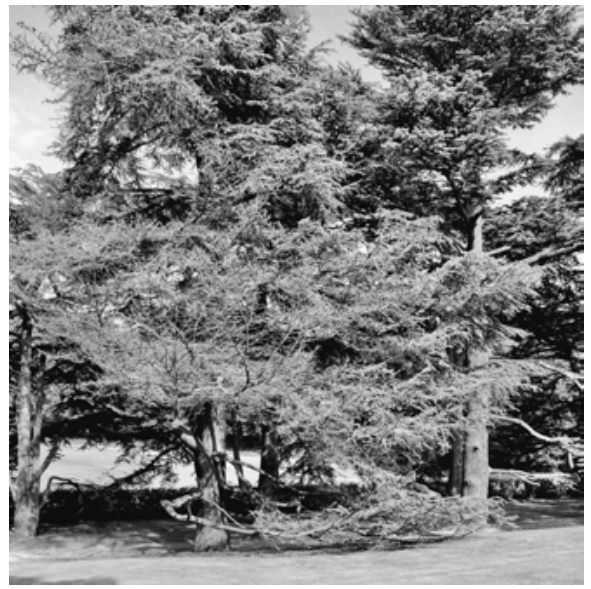

2 Over the past ten years or so the incidence of diseases with trees have increased substantially. For example, some cedars (Cedrus spp.) are threatened by Sirococcus tsugae, a fungal disease that was previously only known on Tsuga, here an instance at Clumber Park.

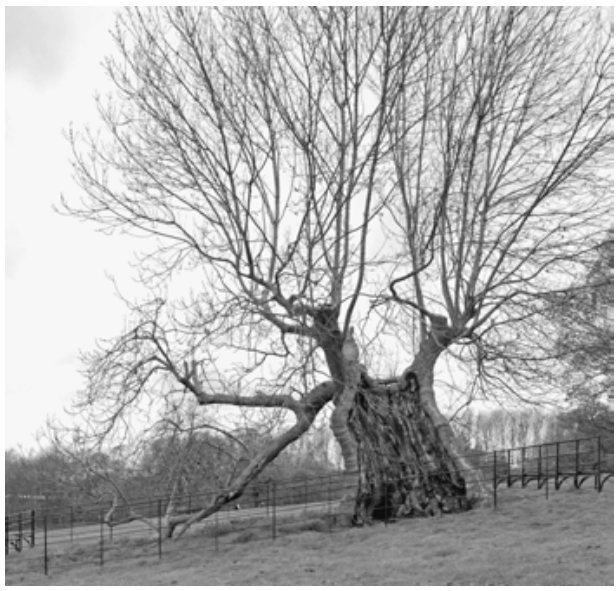

3 Ancient, so-called /veteran trees` will also be increasingly challenged through climate change; simple measures, such as erecting of fences to prevent compaction, may help. This example at Bretton Park, better known as the Yorkshire Sculpture Park.

landscape heritage.< Collectively this would enable >the extent of conservation challenges, management needs and successful strategies to be assessed, presumably enabling policy adjustments as needs arise (White 2014).

\section{Managing adaptation}

One of White's examples of adaptation is the tree and its significance for conservation. Having stated that good planting and establishment practice helps trees to grow strong and robust and is thus a good adaptation measure, she notes that forest modelling research indicates the unsuitability of certain tree species. Beech and oak will be increasingly challenged in the south of the country, whereas sweet chestnut (Castanea sativa) will be more suitable. While ash (Fraxinus excelsior) is normally adaptable to various situations, it is now threatened by chalara disease (Hymenoscyphus fraxineus). Sycamore (Acer pseudoplatanus) and birch (Betula pendula) could become marginal. Holm oak (Quercus ilex) and Turkey oak (Quercus cerris) are likely to adapt well, whereas cedars (Cedrus spp.) are threatened by a fungal disease (Sirococcus tsugae) (Fig. 2). Ancient, so-called `veteran trees $\measuredangle$ will also be increasingly challenged (Fig. 3) (Ray et al. 2010). The context for forest modelling is 
primarily to assess potential for forestry and woodland planting, but climate change has also been blamed for the demise of trees in designed landscapes (where they can be looked after to some extent), such as Beech Avenue in Kingston Lacey owned by the National Trust (Peterkin 2008). This was presented as a showcase for the effects of climate change and was later replaced with hornbeam, which was considered to be more resilient. In this instance the resilience of beech trees might have been ensured by good planting practice, but here the Trust appeared to prioritise propaganda over historical accuracy. ${ }^{4}$

It was as a result of the Trust's stated philosophy that 'gardens and parks must evolve in response to climate change. (It notes that it >will do everything it can to conserve its unique collection of highly significant gardens and parks, but will be more flexible in its approach to less historically significant ones. This provides scope for both interpretation and reinterpretation of significance and historic significance. The Environmental Standard interprets the latter as `historically significant layout and characteristics`, and considers this as something distinct from >managing change $<$. It sees this as offering >many exciting new opportunities for horticultural innovation`, rather than managing change in order to be able to retain historic integrity. It proposes a tiered approach to climate change adaptation: good husbandry practice ensures that plants are in optimum health in order to withstand the effects of climatic change, and that they can be retained in situ. The range of properties owned by the Trust enables a climatically challenged plant collection to be moved to a garden in a different region. Management of ephemeral plantings, such as annuals, biennials, bulbs and perennials, should be in response to changing climatic conditions "spirit of the place« provided these can be managed sustainably. Finally, it suggests that if historic structural planting, such as avenues and clumps, are to be replaced, >consideration will be given to using species likely to adapt or cope in future climatic conditions, whilst perpetuating the original layout/design and character. $<$ As was the case at Kingston Lacey (above), species likely to cope with new or rapidly changing climatic conditions will be favoured . This is instead of a statement such as: >the feasibility for adaptive horticultural practice will be explored for historic structural planting in parks and gardens $\triangleleft$ Historic accuracy is clearly a secondary consideration. In this instance, since the only climate-related problems with beech have occurred in the woodlands of the Chilterns, an area with thin soils, a properly prepared soil mix of sufficient depth, would have sufficed to enable young trees to mature (Hitchmough et al. 2010, 155f.).

Another interesting case is the way in which the energy cost of lawn management will be affected by climate change. A case study in Environmental Standard showed that that with every $1^{\circ} \mathrm{C}$ which will lead to a 21-day increase in growing season, the raverage annual undiscounted climate change-induced lawn maintenance cost for all National Trust gar-

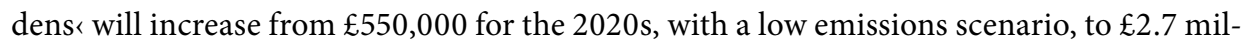
lion for the 2080s, with a high emissions scenario. The suggestion made here in order to reduce these costs would be to accept different standards such as raising the cut or using different -presumably larger - equipment and bio-fuels (Hitchmough et al. 2010, 113). Higher cuts can affect the aesthetic appearance of ornamental areas, so this would have to 
be done with due care. It is unclear whether increasing drought and the subsequent lack of grass have been considered in this scenario, since in this instance there may be little grass to mow.

\section{Conclusions}

The above comments reveal that despite political distractions considerable progress has been made in the issues relating to climate change in the UK. In the context of parks and gardens much thought and effort have been given to mitigation, with measures to reduce carbon emissions and, by extension, slow the process of climate change. In order to do this sustainable approaches have been adopted, involving both old and new methods, both proven and innovative, and they have been applied to many historic parks and gardens. These are seen as ideal sites to accommodate change and build resilience, serving as exemplars for planning, implementation and management. The National Trust's Environmental Standard for Gardens and Parks (2010) provides evidence of how practices have been implemented in the organisation, but also much more widely within other private and public organisations. This publication has proven to be a good basis to disseminate and take over ideas that are now much more commonplace.

Given the uncertainty about what climate change entails in the context of a particular site, adaptation to climate change is much more problematic. The main efforts within parks and gardens have focussed on building resilience through good planting practice and stewardship. The focus here has been on managers and staff being well equipped to deal with the challenges, overcoming a resistance to change and lack of urgency in adopting more sustainable practices. Progress in implementation though is hindered by the fact that despite these efforts more than a third of the British population is not worried about climate change. It is clear that more must be done to engage the general public, which currently does not appear to grasp the links between extreme weather events, pests and diseases, and migration.

Historic parks and gardens are a finite resource and it is important to maintain historic integrity and quality and adopt good conservation practice (Fig. 4). In Great Britain the Conservation Management Plan is promoted for individual sites as a tool, not only for setting out future objectives, but also as a way of monitoring the effects of climate change and recording and assessing climate adaptation and mitigation measures. One of the main current challenges is the proliferation of pests and diseases in trees. Long-term monitoring would be able to verify the success of particular adaptation techniques and perhaps develop these into wider strategies. General conservation principles can help guide periodic renewal, repair and restoration as both adaptation strategies and a way to manage change. Resilience may well be improved by good horticultural practice, and systematic recording may well assist in defining more generally applicable strategies. Yet it recognises that its success relies on the presence of well-qualified personnel and the ability to share experiences. 
4 Historic parks and gardens are a finite resource and it is important to maintain historic integrity and quality and adopt good conservation practice. In Great Britain, such as at Kew, the Conservation Management Plan provides a tool, not only setting out future objectives, but also as a way to monitor the effects of climate change and record and assess climate adaptation and mitigation measures.

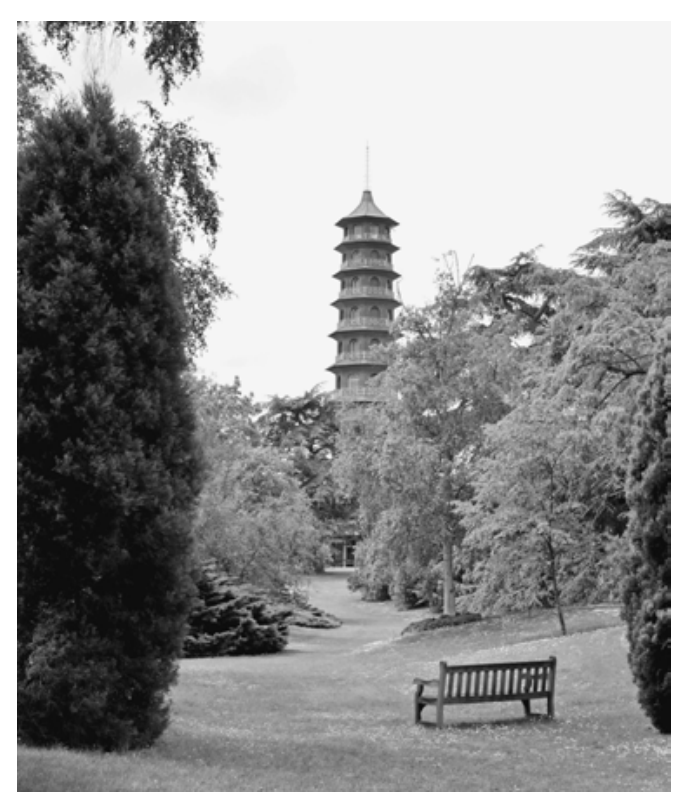

In a political climate of shrinking budgets it may be the ability to share experiences that could help in defining appropriate adaptive strategies. But whereas the first report on the topic, Gardening in a Global Greenhouse (2002), was produced by staff at the University of Reading in association with the National Trust, English Heritage and the Royal Horticultural Society, these organisations have since gone off and produced their own policy papers targeting their own specific audiences. From these papers it is clear that, however helpful, there is overlap and there are lacunas and misunderstandings which could easily be resolved through joint efforts. Given the scale of projected climate change further collaborative thinking is not just a matter of political courtesy, but also of the greatest essence.

\section{Bibliography}

Bisgrove, Richard; Hadley, Paul (2002): Gardening in the Global Greenhouse: The impacts of climate change on gardens in the UK. Oxford: UK Climate Impacts Programme.

Fluck, Hannah (2016): Climate Change Adaptation Report. https://research.historicengland.org.uk/Report. aspx?i=15500 (13.11.2018).

Historic England (n.d.): Responses to Climate Change. https://historicengland.org.uk/research/current/threats/ heritage-climate-change-environment/reponses/ (13.11.2018).

Hitchmough, James; Houldcroft, Eleanor; Dunnett, Nigel (2010): Environmental Standard for Gardens and Parks (The National Trust). 
Hulme, Mike et al. (2002): Climate Change Scenarios for the United Kingdom: The UKCIP02 Scientific Report. Tyndall Centre for Climate Change Research, School of Environmental Sciences, University of East Anglia, Norwich, UK.

National Trust (2013): Trees being felled on beech avenue at Kingston Lacey. Press release. http://www.ntsouth west.co.uk/2013/01/trees-being-felled-on-beech-avenue-at-kingston-lacy/ (13.11.2018).

National Trust (2017): Annual Report 2016/17. https://www.nationaltrust.org.uk/documents/annualreport-201617.pdf (13.11.2018).

Peterkin, Tom (2008): Traditional forests endangered by climate change and disease. In: The Telegraph, 03.08. 2008. https://www.telegraph.co.uk/news/2493606/Traditional-forests-endangered-by-climate-changeand-disease.html (13.11.2018).

Ray, Duncan; Morison, James; Broadmeadow, Mark (2010): Climate Change: Impacts and adaptation in England's woodlands. https://www.forestry.gov.uk/pdf/FCRN201.pdf/\$file/FCRN201.pdf (13.11.2018).

Steentjes, Katharine et al. (2017): European Perceptions of Climate Change: Topline findings of a survey conducted in four European countries in 2016. Cardiff: Cardiff University.

Department for Environment, Food and Rural Affairs (n.d.): Xylella fastidiosa. https://planthealthportal.defra. gov.uk/pests-and-diseases/high-profile-pests-and-diseases/xylella/ (13.11.2018).

Webster, Eleanor; Cameron, Ross; Culham, Alastair (2017): Gardening in a Changing Climate. London: Royal Horticultural Society.

White, Jenifer (2014): Conserving historic parks and gardens in a changing climate. In: Gardens and Landscape in Historic Building Conservation. Ed. by Marion Harney. New York et al.: John Wiley, 207-218.

Woudstra, Jan (2014): Climate change and historic gardens in the United Kingdom. In: Historic Gardens and Climate Change: Recommendations for preservation. Ed. by Michael Rohde and Heiner Krellig. Leipzig: Seemann Henschel GmbH, 88-91.

\section{Picture Credits}

1 Jan Woudstra, July 2015; 2 Jan Woudstra, May 2018; 3 Jan Woudstra; 4 Jan Woudstra, June 2016

Plates XIV-XVI Rob Collins/National Trust Images/John Hammond. 


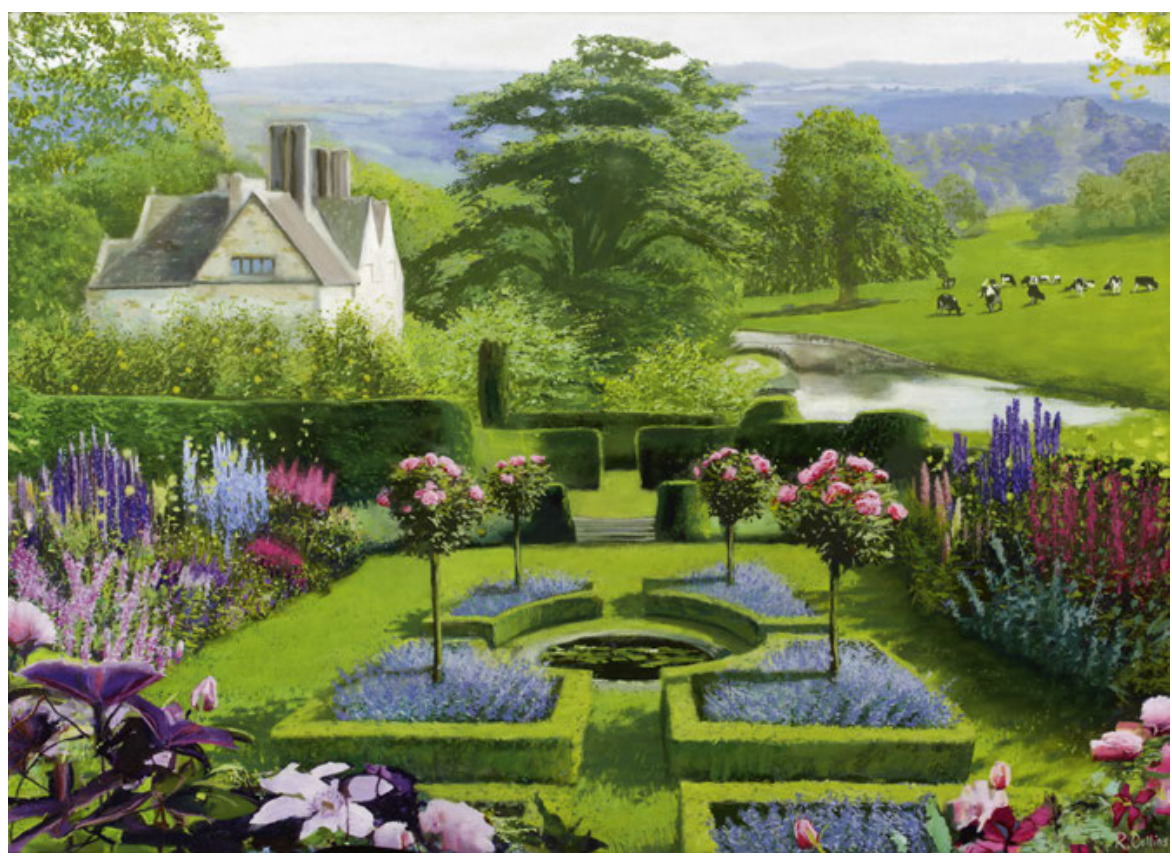

XIV

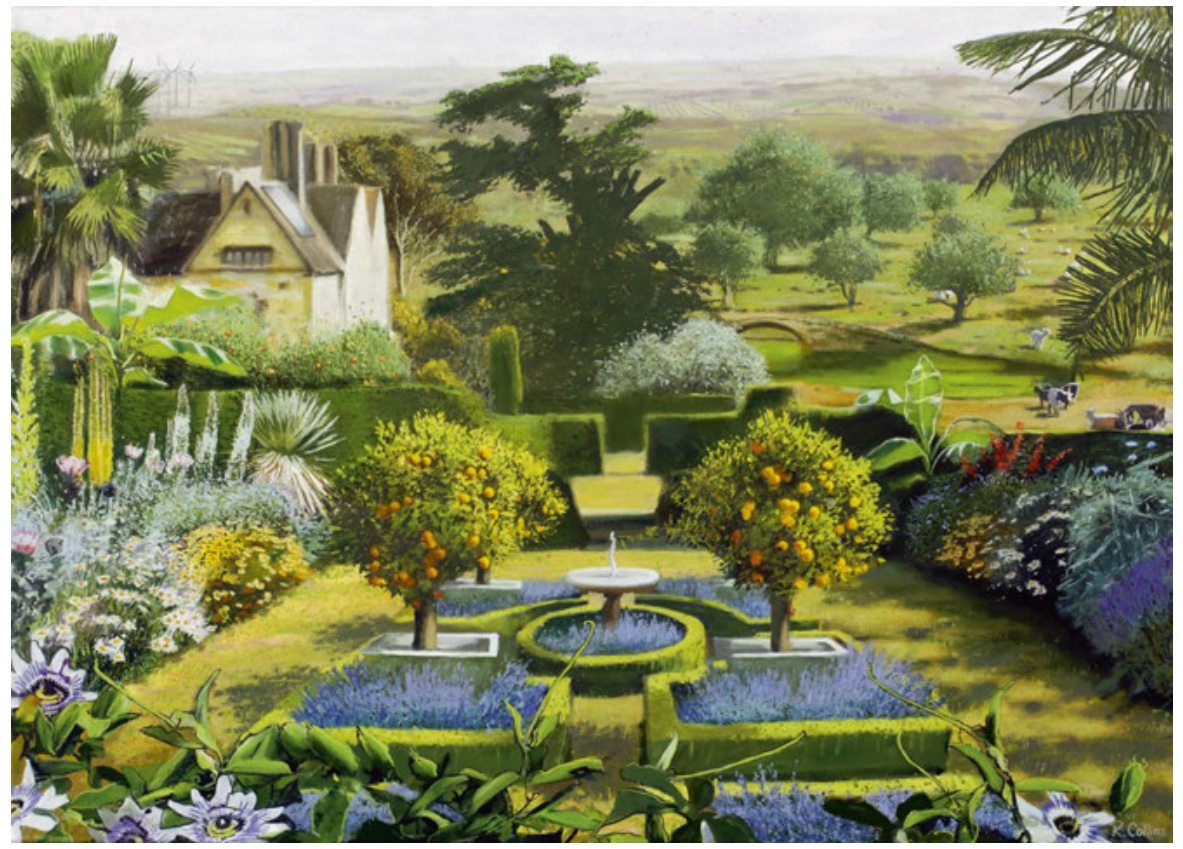




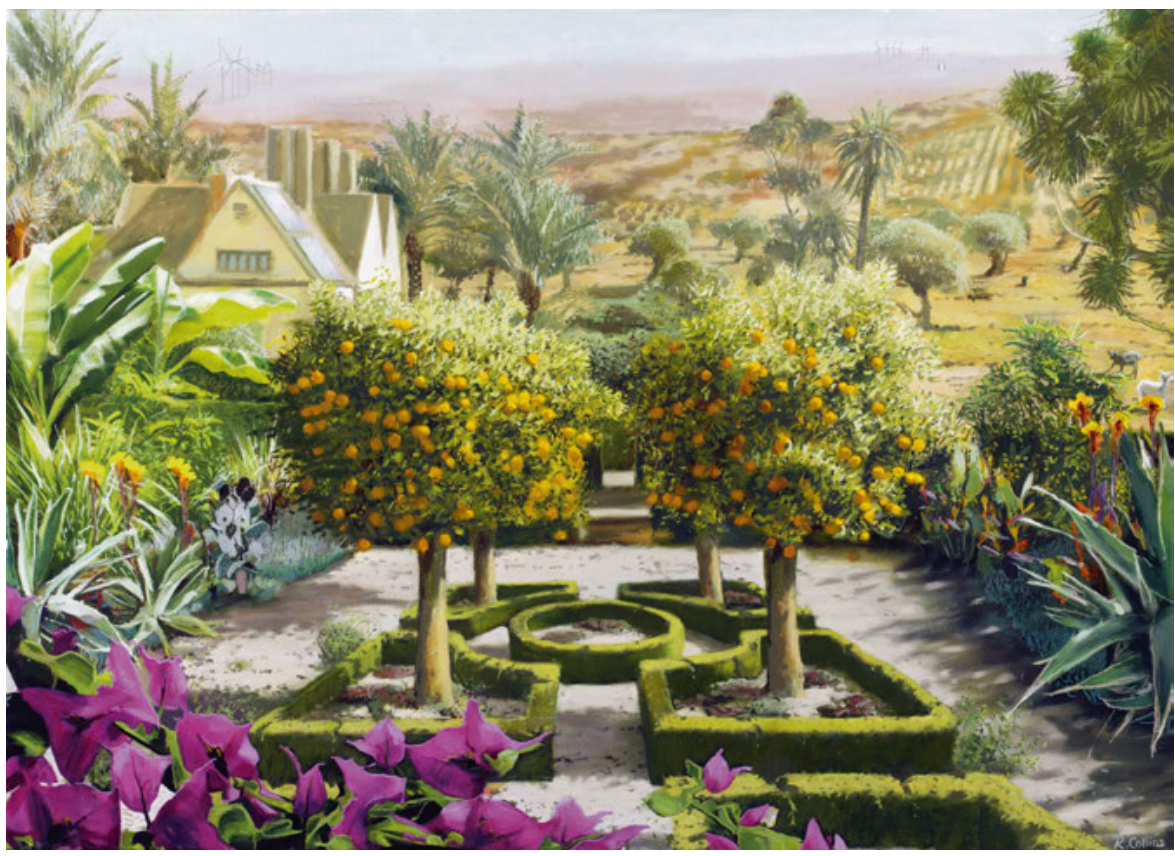

XVI

XIV-XVI The National Trust 2010 travelling exhibition on climate change entitled $>$ A plant in timer included three paintings, which feature a typical, but imaginary National Trust property, with a house set in parkland with lake. The first painting (Taf. XIV) shows the 2010 situation; the second painting (Taf. XV) a scenario of plus $2^{\circ} \mathrm{C}$; and the third painting (Taf. XVI) a scenario of plus $4^{\circ} \mathrm{C}$. 